\title{
FOREIGN INVESTMENT INFLOWS AND INDUSTRIAL SECTOR GROWTH IN INDIA- AN EMPIRICAL STUDY
}

\author{
Mousumi Bhattacharya ${ }^{1}$
}

\begin{abstract}
The paper aims to study the causal relationship between foreign investment inflows and industrial sub-sectors growth pattern of the Indian economy during the post liberalization period (1996-97:Q1 to 2009-10:Q2). The stationarity of the variables being checked than Granger causality test is conducted in a multivariate VAR framework at VECM form to identify if any causal relationship is there amongst the variables. Regression analysis is also done with the same dataset. It is seen that industrial sector at the sub-sectoral level influences foreign investment inflows.
\end{abstract}

Key words: Foreign investment inflows, Granger causality, industrial sector growth

JEL Codes: F21, O11

\section{Introduction}

As the economy progresses the gross domestic product enlarges followed by a change in economic activity which is more inclined towards the tertiary sector (services) and secondary sector (industrial) than towards the primary sector (agricultural). This happens due to high elasticity of industrial and services sector compared to the agricultural sector. Over the years this has led to the growing supremacy of the industrial and services sector and lesser dominance of the agricultural sector. The domestic investment in India has not been large enough to wholly meet investment requirements and so capital inflows from other countries particularly of investment nature have become important. It is true that greater foreign investment inflows bring unambiguous benefits to the economy by generating employment, raising productivity, transferring foreign skills and technology and contributing positively to gross domestic product, gross fixed capital formation and balance of payments. In the years prior to 1991, FDI was permitted only up to 40 percent in certain industries, known As “Appendix I Industries" subject to the discretionary approval by the government. In 1991, FDI was allowed upto 51 percent equity in these industries under the "automatic route". This was latter liberalized in 1997 to enable setting up of 100 percent subsidiaries in the manufacturing sector. The list of products reserved for exclusive manufacture by small-scale industries has been progressively removed from the reservation list, enabling large domestic and foreign firms to enter those product lines. Economic reforms not only relaxed the entry restrictions on domestic and foreign firms but also they liberalized access to intermediate inputs, capital goods and technology. Apart from stimulating export markets and producing foreign exchange revenue, foreign investment inflows also contributed towards servicing debt repayments. To encourage foreign investment inflows, foreign investment policy has continued to be fine tuned by allowing foreign investment in more and more industries under the automatic route. About a third of total global exports are generated by the subsidiaries of MNCs, which bring the vast portion of the FDI. The impact of foreign investments (both FDI and portfolio flows) depends on what form it takes and includes the type of foreign investments, sector, scale, duration and location of business and secondary impacts on the economy. In order to reap the benefits of foreign investments it is crucial to refocus on the perspective apart from merely enhancing the availability of foreign investment. The effect of foreign investment inflows in different sectors was not accounted for in

\footnotetext{
${ }^{1}$ Army Institute of Management, Kolkata, Judges Court Road, Kolkata,e-mail: mbhattacharya9@gmail.com.
} 
many empirical studies conducted in the post reform period. Over the years the composition of foreign investment inflows across three sectors like primary, secondary and tertiary has changed radically and there has been a tremendous shift from foreign investment in primary and the industrial sector to foreign investment in the tertiary sector. The productivity spillover effect differs across the three sectors (i.e. primary, secondary and tertiary) so the growth effects of foreign investment inflows depend upon the potential of different sectors. Here an attempt is made to access the growth implications of foreign investment inflows in the industrial sector at the subsectoral level. In order to access whether the industrial sector at the sub-sectoral level influences foreign investment inflows certain econometric (stationarity test, cointegration, causality test) and statistical techniques (regression) have been employed. The findings suggest that each of the subsectors of the industrial sector i.e manufacturing sector, mining and quarrying sector and electricity sector, water and gas supply sector contributes towards foreign investment inflows during the post liberalization period. The research is first of its kind to access the causal relationship between industrial sector growth at the sub-sectoral level and foreign investment inflows in India.

\section{Literature review}

Almost all empirical studies till data use aggregate data to study the growth effects of FDI across sectors and pay diminutive attention to the composition of FDI. However, some major exceptions were noticed in the study of Alfaro (2003) and Aykut and Sayek (2007). After controlling for macroeconomic and institutional factors Alfaro (2003) applied cross-country panel data on sector-specific FDI flows and found that foreign direct investment has significantly positive growth effects in the manufacturing sector only. His opinion was that in the industrial sector only spillover effects takes place of FDI related technology and knowledge. According to Rodriguez-Clare, 1996, in the industrial sector there is use of intermediate inputs by foreign investors which in turn creates positive externalities. This is due course of time helps local producers to encash on a larger variety of inputs and thereby increase their productivity. According to UNCTAD (2001) a broad variety of linkage intensive activities in observed only in the industrial sector, since the linkages between local suppliers and affiliates of foreign bodies is limited in the agricultural sector. The scope is also limited in the services sector because of the process of dividing production into separate distinct stages and than subcontracting out to independent domestic firms which is time consuming and cost effective. In the study conducted by Aykut and Sayek (2007), he was of the opinion that if efficiency-seeking reasons motives FDI than industrial sector are most benefitted due to the knowledge and technology spillovers. He considered not only the aggregate inflows but also the detailed composition of FDI inflows but could conclude positive growth effects only when FDI in industrial sector was prominent. FDI was considered an important vehicle for transferring technology in the work conducted by Findlay (1978) and Wang and Bloomstrom (1992) and they were of the opinion that, this transfer of technology was observed more in the tertiary and secondary sector compared to the primary sector. In Indian context Kathuria (2002) was the first to estimate the impact of foreign investment on productivity and spillovers to domestic firms in Indian manufacturing sector in the liberalization period 1989-90 to 1996-97.

\section{Data Source}

The data used in the study are foreign investments inflows (both FDI and portfolio flows) (FI) in India from 1996-97: Q1 to 2009-10:Q2 (fig. no. 1). The contributions of the industrial sector in the quarter- wise GDP estimates at constant (1999-2000) prices are taken. At the sub-sectoral level the contribution of manufacturing (MAN), mining and quarrying (MQ) and electricity water and gas supply (EWG) to the quarter wise GDP, measuring growth of the respective sub-sectors over the years are taken. The data have been retrieved from various issues of the Reserve of India bulletin. 


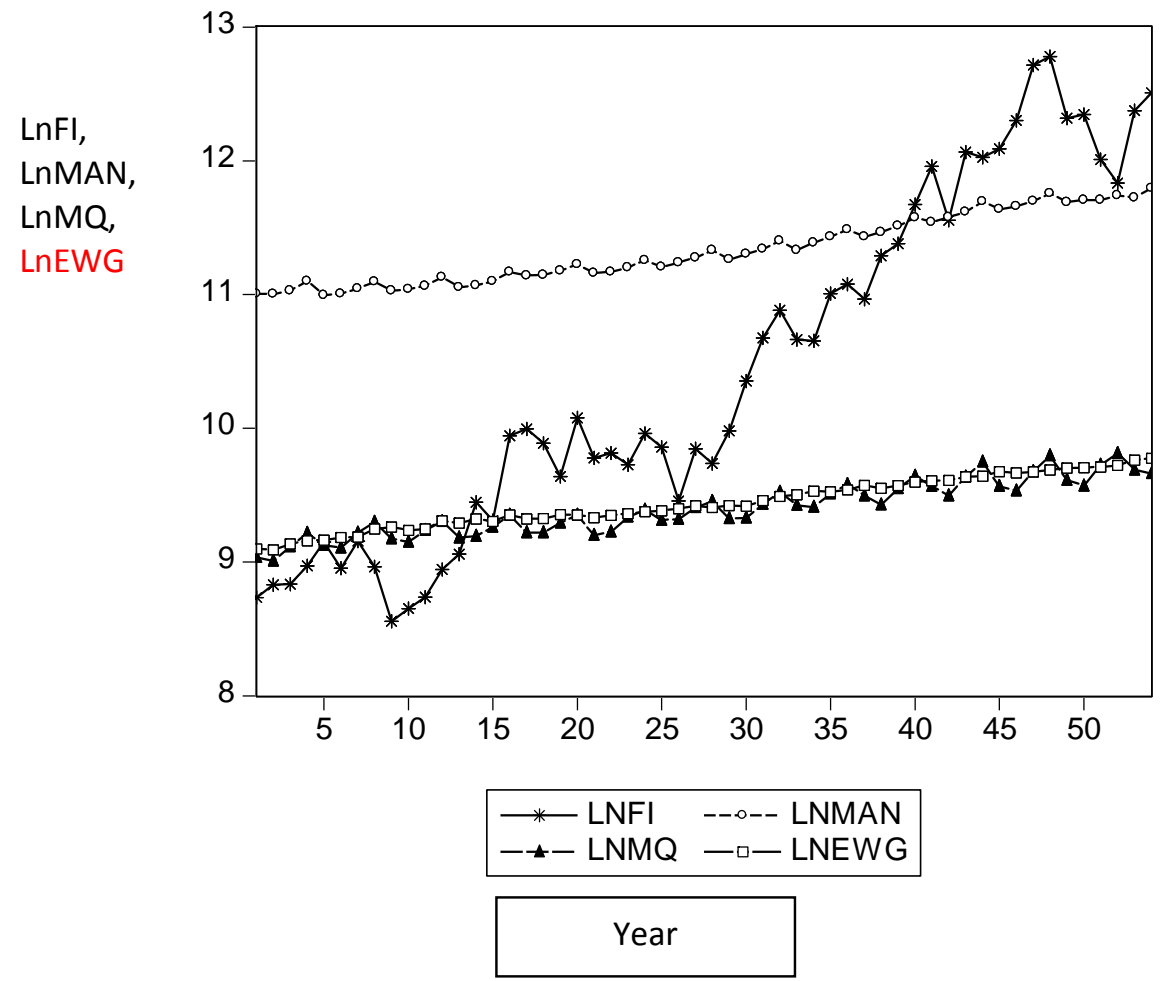

Fig. no. 1: Logarithmic values of foreign investment inflows (FI), manufacturing sector's contribution to GDP (MAN), mining and quarrying sector's contribution to GDP(MQ), electricity water and gas supply sector's contribution to GDP(EWG)

\section{Methodology}

The various statistical and econometric techniques that are employed include: -

\section{- Statistical Analysis}

- Econometric Analysis

\section{Statistical Analysis}

A simple regression model is used to predict whether industrial sector at the sub-sectoral level is contributing towards foreign investment inflows in the country for the time period 199697:Q1 to 2009-10: Q2.

The linear regression equation used here may be represented as: -

$$
L n F I_{t}=\alpha+\beta_{1} \operatorname{LnMAN}_{t}+\beta_{2} \operatorname{LnMQ}_{t}+\beta_{3} L n E W G_{t}+\varepsilon_{t}
$$

where $\alpha$ is the constant term. MAN represents the manufacturing sector's contribution to GDP, MQ denotes the mining and quarrying sector's contribution to GDP, EWG denotes the electricity water and gas supply's contribution to GDP and FI represents foreign investment inflows. $\varepsilon_{t}$ is the error term. $\beta_{1}, \beta_{2}, \beta_{3}$ are the coefficients in the regression equation (1) which are to be estimated. 


\section{Econometric Analysis}

The objective of the study is to examine causality between foreign investment inflows and industrial sector growth pattern from first quarter 1996 to second quarter 2010 by employing Granger causality test in a Vector Autoregressive (VAR) framework.

\section{Stationarity Test}

Three types of stationarity test like Augmented Dickey Fuller (ADF) [1979], Phillips-Perron (PP) [1988] and Kwiatkowski, Phillips, Schmidt and Shin (KPSS) [1992] are performed with the variables in order to check their stationarity.

\section{Cointegration Test}

Cointegration test is done as all the variables are integrated of the same order and this test helps to determine whether the variables involved in the study have a long-run equilibrium relationship.

Johansen (1988) and Johansen and Juselius (1990) cointegration technique have been applied to identify the long term relationship between the variables. According to Johansen-Juselius method the number of co-integrating vectors is accessed based on two test statistics, viz., the Trace Statistic and the Maximal Eigenvalue Statistic. The null hypothesis of ' $r$ ' cointegrating vector(s) against the alternative of ' $r+1$ ' cointegrating vectors is tested in Maximal Eigen value statistic whereas the null hypothesis of, at most, ' $r$ ' cointegrating vector(s) against the alternative hypothesis of more than ' $\mathrm{r}$ ' cointegrating vector is tested in Trace statistic. The Granger Causality test is applied in the framework of error correction mechanism (ECM) if all the variables in the study is I(1) and cointegrated.

\section{Granger Causality test in a VECM framework}

In order to determine the direction of causality between the variables FI, MAN, MQ and EWG Granger Causality test is conducted. To study the lag effect of the variables, the optimal lag length $\mathrm{p}$ (which is 3 in the present study) (table no. 1) is chosen based on combination of information criteria like LR or FPE or AIC or SC or HQIC.

Table no.1.

VAR Lag Order Selection Criteria [D(LnFI), D(LnMAN), D(LnMQ) and D(LnEWG)]

\begin{tabular}{|c|c|c|c|c|c|c|}
\hline Lag & Log L & LR & FPE & AIC & SC & HQIC \\
\hline 0 & 276.8149 & NA & $2.14 \mathrm{e}-10$ & -10.91260 & -10.75963 & -10.85435 \\
\hline 1 & 302.3468 & 45.95744 & $1.47 \mathrm{e}-10$ & -11.29387 & -10.52906 & -11.00263 \\
\hline 2 & 355.8641 & 87.76845 & $3.31 \mathrm{e}-11$ & -12.79457 & -11.41791 & -12.27033 \\
\hline 3 & 389.4409 & $49.69356^{*}$ & $1.70 \mathrm{e}-11^{*}$ & $-13.49763^{*}$ & $-11.50913^{*}$ & $-12.74040^{*}$ \\
\hline
\end{tabular}

*indicates lag order selected by the criterion

D: first differenced of the concerned variables

When two variables are I(1) and cointegrated than the direction of causal relationship is detected in a VECM framework. In presence of cointegration the incorporation of error correction term helps to determine how changes in the dependent variable are a function of the level of disequilibrium in the cointegrating relationship as well as changes in other explanatory variable(s). The long-run adjustment of cointegration variable is captured by the error correction term (ECT). In order to detect both short and long run causal relationship among variables the VECM is very helpful. The VECM equations are represented as follows: 


$$
\begin{aligned}
& \Delta L n F I_{t}=\sum_{j=1}^{p-1} \beta_{11, j} \Delta L n F I_{t-j}+\sum_{j=1}^{p-1} \beta_{12, j} \Delta L n M A N_{t-j}+\sum_{j=1}^{p-1} \beta_{13, j} \Delta L n M Q_{t-j}+\sum_{j=1}^{p-1} \beta_{14, j} \Delta L n E W G_{t-j}+\alpha_{1} E C T_{t-1}+\varepsilon_{1 t} \ldots . .(2 a) \\
& \Delta L n M A N_{t}=\sum_{j=1}^{p-1} \beta_{21, j} \Delta L n M A N_{t-j}+\sum_{j=1}^{p-1} \beta_{22, j} \Delta L n F I_{t-j}+\sum_{j=1}^{p-1} \beta_{23, j} \Delta L n M Q_{t-j}+\sum_{j=1}^{p-1} \beta_{24, j} \Delta L n E W G_{t-j}+\alpha_{2} E C T_{t-2}+\varepsilon_{2 t} \ldots . .(2 b) \\
& \Delta L n M Q_{t}=\sum_{j=1}^{p-1} \beta_{31, j} \Delta L n M Q_{t-j}+\sum_{j=1}^{p-1} \beta_{32, j} \Delta L n F I_{t-j}+\sum_{j=1}^{p-1} \beta_{33, j} \Delta L n M A N_{t-j}+\sum_{j=1}^{p-1} \beta_{34, j} \Delta L n E W G_{t-j}+\alpha_{3} E C T_{t-3}+\varepsilon_{3 t} \ldots .(2 c) \\
& \Delta L n E G W_{t}=\sum_{j=1}^{p-1} \beta_{41, j} \Delta L n E G W_{t-j}+\sum_{j=1}^{p-1} \beta_{42, j} \Delta L n F I_{t-j}+\sum_{j=1}^{p-1} \beta_{43, j} \Delta L n M A N_{t-j}+\sum_{j=1}^{p-1} \beta_{44, j} \Delta L n E W G_{t-j}+\alpha_{4} E C T_{t-4}+\varepsilon_{4 t} \ldots(2 d)
\end{aligned}
$$

where $\Delta$ is the first difference operator and $\varepsilon_{1 t}, \varepsilon_{2 t}, \varepsilon_{3 t}$ and $\varepsilon_{4 t}$ are white noise. The error correction term is represented by ECT, and order of the VAR is represented by p, which is translated to lag of $p-1$ in the ECM. $\alpha_{1}, \alpha_{2}, \alpha_{3}$ and $\alpha_{4}$ symbolize the pace of adjustment after the FI, MAN, MQ and EWG deviate from the long-run equilibrium in period $\mathrm{t}-1$.

\section{Findings}

\begin{tabular}{|c|c|c|c|c|c|c|c|}
\hline & Constant & LnMAN & LnMQ & LnEWG & $R^{2}$ & $\bar{R}^{2}$ & F-statistic \\
\hline LnFI & $\begin{array}{l}-46.9229 * * * \\
(1.9742) \\
{[-23.7670]}\end{array}$ & $\begin{array}{l}5.1213 * * * \\
(0.7825) \\
{[6.5440]} \\
\end{array}$ & $\begin{array}{l}-1.3712^{* * *} \\
(0.6424) \\
{[-2.1344]} \\
\end{array}$ & $\begin{array}{l}1.2936 * * * \\
(0.9141) \\
{[1.4151]} \\
\end{array}$ & 0.9596 & 0.9572 & $\begin{array}{l}396.3403 \\
\text { (p value } \\
=0.0000)\end{array}$ \\
\hline
\end{tabular}

\section{Statistical Analysis}

Table no. 2

Regression Results for the Time Period 1996-97:Q1 - 2009-10:Q2

*** indicates significant at $1 \%$ level. Standard errors in ( ) \& t-statistics in [ ]

The results (table no. 2) reveal that LnMAN, LnMQ and LnEWG are each significant at $1 \%$ level in explaining LnFI during the period 1996-97:Q1 to 2009-10:Q2. The $R^{2}$ value of 0.9596 is significant in explaining measurement of goodness of fit of the regression model. The small $\mathrm{p}$ value (0.0000) of the F statistic reveals that the regression is significant. The study has employed various diagnostic tests viz., Jarque Bera normality test, Autoregressive Conditional Heteroskedasticty (ARCH) LM test and Ramsey RESET specification test to examine the validity and reliability of the regression model.

Jarque Bera test statistic (table no. 3) is used for testing whether the residuals of the series are normally distributed. The null hypothesis is of a normal distribution - a small probability value leads to the rejection of the null hypothesis. Here the null hypothesis cannot be rejected (p value $=0.739865$ ) so it can be concluded that the residual series is normally distributed.

Table no. 3 .

Jarque Bera test

\begin{tabular}{|c|c|c|c|c|}
\hline Diagnostic test & Purpose & Test Statistic & Probability & Conclusion \\
\hline Jarque Bera test & Normality & 0.602576 & 0.739865 & Normally distributed \\
& & & & \\
\hline
\end{tabular}


Ramsey's RESET test is general test for misspecification of functional form. The null hypothesis that the functional form is correctly specified is tested and the consequent $F$ statistic and the $\log$ likelihood ratios are reported. Both $F$ and $\chi^{2}$ versions of the test (table no. 4) shows that there is no-apparent non-linearity in the regression model and it can be concluded that the linear model for FI is appropriate.

Table no. 4.

Ramsey RESET Test

\begin{tabular}{|c|c|c|c|}
\hline$F$-statistic & 0.532604 & Prob. $F(1,49)$ & 0.4690 \\
\hline Log likelihood ratio & 0.583785 & Prob. Chi-Square(1) & 0.4448 \\
\hline
\end{tabular}

The ARCH test is used to check the presence of autoregressive conditional heteroskedasticity (ARCH) in the residuals. The ARCH test is one of a joint null hypothesis that all $\mathrm{q}$ lags of the squared residuals have co-efficient values that are not significantly differently form zero. The $F$ statistic is an omitted variable test for the joint significance of all lagged squared residuals. The Obs*R-squared statistic is Engle's LM test statistic, computed as the number of observations multiplied by the co-efficient of multiple correlation and is asymptotically distributed as a $\chi^{2}(q)$. (table no. 5) Both the $F$-version and the LM-statistic are not quiet significant and there is no arch effects in the residuals of the estimated model.

\section{Heteroskedasticity Test - ARCH}

Table no. 5 .

\begin{tabular}{|c|c|c|c|}
\hline$F$-statistic & 0.057373 & Prob. $F(1,51)$ & 0.8117 \\
\hline Obs*R-squared & 0.059556 & Prob. Chi-Square(1) & 0.8072 \\
\hline
\end{tabular}

Finally CUSUM and CUSUMSQ tests are used to check the stability of the parameters in the model. The null hypothesis of parameter stability cannot be rejected at the $5 \%$ level of significance as the cumulated sum stays inside the 95\% confidence band in case of both CUSUM and CUSUMSQ tests. The CUSUM test indicates stability in the equation during the sample period because the line (blue) lies within the $5 \%$ critical lines (fig. no. 2). The CUSUM of squares test shows that the cumulative sum of the squares is within the $5 \%$ significance lines, suggesting that the residual variance is stable. (fig. no. $\mathbf{3}$ ).

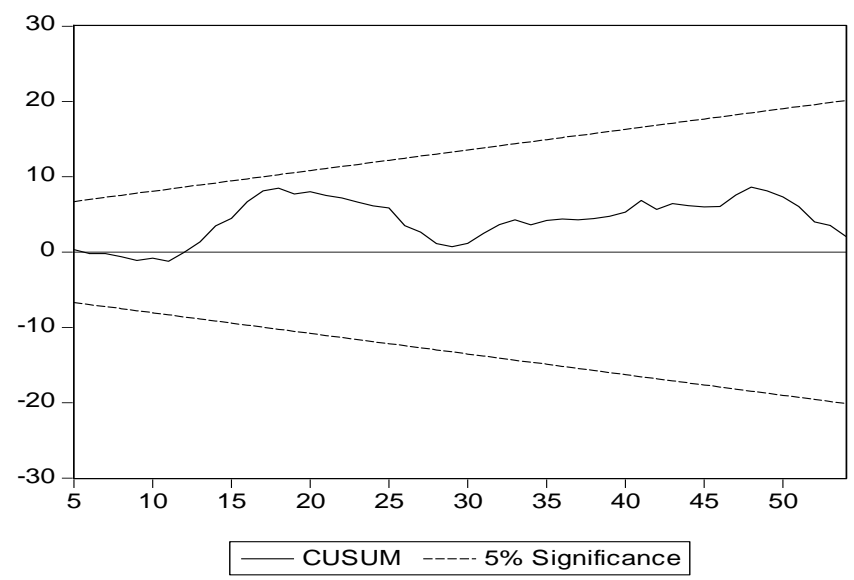

Figure no. 2. - Diagrammatic representation of CUSUM Test 


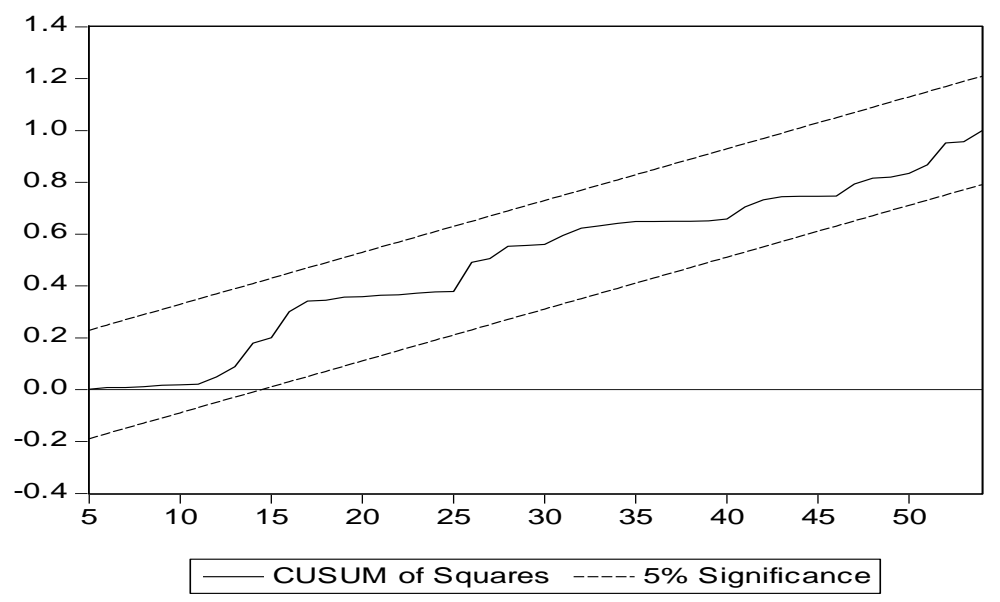

Figure no.3. - Diagrammatic representation of CUSUMSQ Test

\section{Econometric Analysis}

\section{Stationarity Test}

The results of the $A D F$ and $P P$ test are reported in table no.6. The lag length is chosen based on values of SIC. KPSS test is done with Newey- West using Bartlett Kernel automatic bandwidth selection method.

Table no.6.

Test of Unit Root Hypothesis without Trend (1996-97:Q1 to 2009-10:Q2)

\begin{tabular}{|c|l|c|c|c|c|c|c|}
\hline & \multicolumn{2}{|c|}{ ADF Statistic } & \multicolumn{2}{|c|}{ PP Test } & \multicolumn{2}{c|}{ KPSS } \\
\hline \multirow{2}{*}{ Series } & & Test Statistic & Lags & Test Statistic & Lags & Test Statistic & $\begin{array}{c}\text { Band } \\
\text { width }\end{array}$ \\
\hline \multirow{3}{*}{ LnFI } & Level & -0.44574 & 0 & -0.44574 & 0 & $0.83457^{* * *}$ & 6 \\
\cline { 2 - 8 } & $\begin{array}{l}\text { First } \\
\text { Difference }\end{array}$ & $-8.52138^{* * *}$ & 0 & $-8.52138^{* * *}$ & 0 & 0.061344 & 1 \\
\hline \multirow{3}{*}{ LnMAN } & Level & 0.908304 & 5 & 1.721770 & 5 & $0.85696^{* * *}$ & 6 \\
\cline { 2 - 8 } & $\begin{array}{l}\text { First } \\
\text { Difference }\end{array}$ & $-2.712507^{*}$ & 4 & $-28.5262^{* * *}$ & 4 & 0.290160 & 12 \\
\hline \multirow{3}{*}{ LnMQ } & Level & 0.563884 & 4 & -2.289973 & 4 & $0.99881^{* * *}$ & 5 \\
\cline { 2 - 8 } & $\begin{array}{l}\text { First } \\
\text { Difference }\end{array}$ & $-3.560471^{* *}$ & 3 & $-19.1446^{* * *}$ & 3 & 0.257879 & 11 \\
\hline LnEWG & Level & -0.642998 & 1 & -0.347211 & 1 & $0.88347^{* * *}$ & 6 \\
\cline { 2 - 8 } & $\begin{array}{l}\text { First } \\
\text { Difference }\end{array}$ & $-10.4666^{* * *}$ & 0 & $-10.4666^{* * *}$ & 0 & 0.187710 & 21 \\
\hline
\end{tabular}

(a)The critical values are those of MacKinnon (1991).

(b) ${ }^{* * *}$, ** and $*$ represent the rejection of null hypothesis at $1 \%, 5 \%$ and $10 \%$ levels of significance respectively.

According to ADF, PP and KPSS tests, it is seen that LnFI, LnMAN, LnMQ and LnEWG are I (1) processes 


\section{Cointegration Test}

Table no. 7 represents the Johansen Cointegration Test results. It is seen that all the variables are I(1). The null hypothesis cannot be accepted in the cases of both the Trace statistic and Max-Eigen value statistic indicating a long-run relationship among the variables. Table no.7 shows that the number of statistically significant cointegration vectors is equal to 3 for Trace statistic and 2 for Max-Eigen value statistic.

Johansen -Juselius Cointegration Test Results

Table no. 7. [no deterministic trend (restricted constant)]

\begin{tabular}{|c|c|c|c|c|}
\hline $\mathrm{H}_{0}$ & $\mathrm{H}_{1}$ & $\lambda_{\text {trace }}$ & $C V_{(\text {trace, } 5 \%)}$ & Prob** \\
\hline$r=0$ & $r \geq 1$ & 133.2968 & 54.07904 & $0.0000^{* *}$ \\
\hline$r \leq 1$ & $r \geq 2$ & 60.98654 & 35.19275 & $0.0000^{* *}$ \\
\hline$r \leq 2$ & $r \geq 3$ & 21.92788 & 20.26184 & $0.0292^{* *}$ \\
\hline$r \leq 3$ & $r \geq 4$ & 8.695916 & 9.164546 & 0.0613 \\
\hline $\mathrm{H}_{0}$ & $\mathrm{H}_{1}$ & $\lambda_{\max }$ & $C V_{(\max , 5 \%)}$ & Prob** $^{* *}$ \\
\hline$r=0$ & $r=1$ & 72.31025 & 28.58808 & $0.0000^{* *}$ \\
\hline$r \leq 1$ & $r=2$ & 39.05866 & 22.29962 & $0.0001^{* *}$ \\
\hline$r \leq 2$ & $r=3$ & 13.23196 & 15.89210 & 0.1252 \\
\hline$r \leq 3$ & $r=4$ & 8.695916 & 9.164546 & 0.0613 \\
\hline
\end{tabular}

(a) $r$ is the number of cointegrating vectors.

(b)Trace test and Max-eigen value test indicates 3 cointegrating equation and 2 cointegrating equation at the $5 \%$ level of significance.

(c)* denotes rejection of the null hypothesis at the $5 \%$ level of significance

(d)The critical values (i.e., CVs) are taken from Mackinnon-Haug-Michelis (1999).

\section{Analysis of VECM}

It is observed based on Johansen's cointegration test that the variables have a long run relationship among themselves, so to check the short run dynamics ECM can be used. In table no. 8 below, the cointegrating equations are given along with the equation for changes in FI (first column), changes in MAN (second column), changes in MQ (third column), changes in EWG (fourth column). The incorporation of ECT helps to know whether the past values affect the current values of the variables and enable to predict the future values of the variables. A significant coefficient tells how the past equilibrium errors help in determining the recent outcomes not only that is also tells us about the pace of adjustment of the system towards long-run equilibrium. The individual coefficients of the first difference terms helps to detect the short-run dynamics.

The estimate of lagged coefficients $\triangle L n M A N_{t-1}$ in equation (2a) is positive and statistically significant at $10 \%$ level, implying that higher MAN has a positive impact on FI in the short-run. The estimates of the lagged coefficients $\Delta L n M Q_{t-1}, \Delta L n M Q_{t-3}$ in equation (2a) is negative and statistically significant at $5 \%$ level and $1 \%$ level respectively implying that higher MQ has a negative impact on FI in the short run. The estimates of the lagged coefficients $\Delta L n E W G_{t-2}$ in equation (2a) is positive and statistically significant at $5 \%$ level implying that higher EWG has positive impact on FI in the short run.

The adjustment coefficient on $E C T_{t-2}$ in equation (2b) is positive and statistically significant (at 1\% level), which means that the error term contributes in explaining changes in MAN and a long-term relationship exists between the independent variables and MAN. The estimate of lagged coefficient $\Delta L n M Q_{t-1}, \Delta L n M Q_{t-2}, \Delta L n M Q_{t-3}$ in equation (2b) is negative and statistically 
significant at $1 \%$ level, implying that higher MQ has a negative impact on MAN in the short-run. The estimate of lagged coefficients $\Delta L n E W G_{t-1}, \Delta L n E W G_{t-2}$ in equation (2b) are positive and statistically significant at $1 \%$ and $5 \%$ level respectively, implying that higher EWG has a positive impact on MAN in the short-run.

The estimate of lagged coefficients $\triangle L n M A N_{t-3}$ in equation (2c) is negative and statistically significant at 5\% level, implying that higher MAN has a negative impact on MQ in the short-run. The estimate of lagged coefficients $\Delta L n E W G_{t-1}, \Delta L n E W G_{t-2}, \Delta L n E W G_{t-3}$ in equation (2c) is positive and statistically significant at 5\%,1\% and 1\% level respectively, implying that higher EWG has a positive impact on MQ in the short-run.

The adjustment coefficient on $E C T_{t-4}$ in equation (2d) is positive and statistically significant (at 5\% level), which means that the error term contributes in explaining changes in EWG and a long-term relationship exists between the independent variables and EWG. The estimate of lagged coefficient $\Delta L n F I_{t-1}$ in equation (2d) is negative and statistically significant (at $10 \%$ level), implying that higher FI has a negative impact on EWG in the short run.

\section{Vector Error Correction Estimates}

\begin{tabular}{|c|c|c|c|c|}
\hline Vector Error Correcti & timates & & & \\
\hline Included observations & fter adjustme & & & \\
\hline Cointegrating Eq: & CointEq1 & & & \\
\hline LnFI(-1) & 1.000000 & & & \\
\hline LnMAN(-1) & -13.59798 & & & \\
\hline & $(0.96104)$ & & & \\
\hline & {$[-14.1493]$} & & & \\
\hline & & & & \\
\hline $\operatorname{LnMQ}(-1)$ & 17.26435 & & & \\
\hline & $(2.34419)$ & & & \\
\hline & [ 7.36475] & & & \\
\hline LnEWG(-1) & -5.369895 & & & \\
\hline & $(1.80035)$ & & & \\
\hline & [-2.98269] & & & \\
\hline & & & & \\
\hline $\mathrm{C}$ & 32.47857 & & & \\
\hline & (1.97019) & & & \\
\hline & [ 16.4850$]$ & & & \\
\hline Error Correction: & $\mathrm{D}(\mathrm{LnFI})$ & D(LnMAN) & D(LnMQ) & D(LnEWG) \\
\hline CointEq1 & -0.043618 & 0.074912 & 0.021156 & 0.021083 \\
\hline & $(0.13478)$ & $(0.01180)$ & $(0.01716)$ & $(0.01024)$ \\
\hline & {$[-0.32362]$} & {$[6.35094] * * *$} & [1.23312] & {$[2.05892]^{* *}$} \\
\hline $\mathrm{D}(\operatorname{LnFI}(-1))$ & -0.042716 & -0.022284 & -0.023662 & -0.023689 \\
\hline & $(0.17583)$ & $(0.01539)$ & $(0.02238)$ & $(0.01336)$ \\
\hline & {$[-0.24293]$} & {$[-1.44811]$} & {$[-1.05722]$} & {$[-1.77327]^{*}$} \\
\hline $\mathrm{D}(\operatorname{LnFI}(-2))$ & -0.003005 & -0.014021 & 0.016499 & 0.023625 \\
\hline & $(0.18240)$ & $(0.01596)$ & $(0.02322)$ & $(0.01386)$ \\
\hline & {$[-0.01647]$} & {$[-0.87837]$} & [0.71063] & [1.70489] \\
\hline
\end{tabular}




\begin{tabular}{|c|c|c|c|c|}
\hline \multirow[t]{3}{*}{$\mathrm{D}(\operatorname{LnFI}(-3))$} & 0.162321 & -0.002977 & 0.032260 & 0.000923 \\
\hline & $(0.17415)$ & $(0.01524)$ & $(0.02217)$ & $(0.01323)$ \\
\hline & {$[0.93207]$} & {$[-0.19530]$} & [1.45530] & [0.06973] \\
\hline \multirow{3}{*}{$\mathrm{D}(\operatorname{LnMAN}(-1))$} & 3.101466 & 0.118908 & 0.171599 & 0.170005 \\
\hline & $(1.82963)$ & $(0.16012)$ & $(0.23289)$ & $(0.13900)$ \\
\hline & [1.69513]* & [0.74261] & {$[0.73682]$} & {$[1.22302]$} \\
\hline \multirow[t]{3}{*}{ D(LnMAN(-2)) } & -1.416852 & -0.053358 & 0.036498 & -0.045987 \\
\hline & $(1.90600)$ & $(0.16680)$ & $(0.24261)$ & $(0.14481)$ \\
\hline & {$[-0.74336]$} & {$[-0.31988]$} & [0.15044] & {$[-0.31758]$} \\
\hline \multirow[t]{3}{*}{$\mathrm{D}(\operatorname{LnMAN}(-3))$} & 1.234418 & -0.431425 & -0.429475 & -0.205350 \\
\hline & $(1.83688)$ & $(0.16076)$ & $(0.23381)$ & $(0.13955)$ \\
\hline & [0.67202] & [-2.68373] & {$[-1.83683]^{* *}$} & {$[-1.47147]$} \\
\hline \multirow{3}{*}{$\mathrm{D}(\operatorname{LnMQ}(-1))$} & -4.219638 & -1.170176 & -0.913563 & -0.160513 \\
\hline & (1.96539) & $(0.17200)$ & $(0.25017)$ & $(0.14932)$ \\
\hline & {$[-2.14697] * *$} & {$[-6.80325] * * *$} & {$[-3.65175] * * *$} & {$[-1.07497]$} \\
\hline \multirow[t]{3}{*}{$\mathrm{D}(\operatorname{LnMQ}(-2))$} & -0.025271 & -0.809927 & -1.170591 & -0.135217 \\
\hline & $(1.07714)$ & $(0.09427)$ & $(0.13711)$ & $(0.08183)$ \\
\hline & {$[-0.02346]$} & {$[-8.59184]^{* * * *}$} & {$[-8.53773] * * *$} & {$[-1.65231]$} \\
\hline \multirow{3}{*}{$\mathrm{D}(\operatorname{LnMQ}(-3))$} & -4.300408 & -0.461109 & -0.659573 & 0.010227 \\
\hline & $(1.52175)$ & $(0.13318)$ & $(0.19370)$ & $(0.11561)$ \\
\hline & {$[-2.82596] * * *$} & {$[-3.46238] * * *$} & {$[-3.40510] * * *$} & {$[0.08846]$} \\
\hline \multirow[t]{3}{*}{$\mathrm{D}(\operatorname{LnEWG}(-1))$} & 3.644849 & 0.668684 & 0.709766 & -0.140674 \\
\hline & $(2.25572)$ & $(0.19741)$ & $(0.28713)$ & $(0.17138)$ \\
\hline & [1.61583] & {$[3.38727]^{* * *}$} & {$[2.47196]^{* *}$} & {$[-0.82085]$} \\
\hline \multirow[t]{3}{*}{ D(LnEWG(-2)) } & 4.320586 & 0.347747 & 1.198020 & 0.214303 \\
\hline & $(1.99752)$ & $(0.17481)$ & $(0.25426)$ & $(0.15176)$ \\
\hline & {$[2.16298]^{* *}$} & [ 1.98924]** & {$[4.71177]^{* * *}$} & [1.41212] \\
\hline \multirow[t]{3}{*}{$\mathrm{D}(\operatorname{LnEWG}(-3))$} & 2.049350 & 0.200404 & 0.766890 & 0.235871 \\
\hline & (2.17202) & (0.19009) & $(0.27647)$ & $(0.16502)$ \\
\hline & [0.94352] & [1.05428] & {$[2.77384]^{* * * *}$} & [1.42938] \\
\hline R-squared & 0.308955 & 0.828733 & 0.910878 & 0.258977 \\
\hline Adj. R-squared & 0.084832 & 0.773187 & 0.881973 & 0.018645 \\
\hline F-statistic & 1.378506 & 14.91977 & 31.51328 & 1.077580 \\
\hline
\end{tabular}

*** denotes statistical significance at $1 \%$ level of significance, ** denotes statistical significance at $5 \%$ level and * denotes statistical significance at $10 \%$ level of significance.

Standard errors in ( ) and t-statistics in [ ].

\section{Causality Test with VECM}

Table no. 9 reports the results of VEC Granger causality test. Uni- directional causality is observed from all the sub-sectors of the industrial sector (manufacturing, mining and quarrying and electricity water and gas supply) towards foreign investment inflows. Feedback causality is observed between foreign investment inflows and growth of electricity water and gas supply sector. Unidirectional causality is observed from mining and quarrying sector's growth to manufacturing 
sector's growth. Unidirectional causality is observed from electricity water and gas supply sector's growth to both manufacturing and mining and quarrying sectors' growth.

VEC Granger Causality/Block Exogeneity Wald Tests
\begin{tabular}{|c|c|c|c|}
\hline Dependent variable: D(LnFI) & \\
\hline Excluded & Chi-sq & df & Prob. \\
\hline D(LnMAN) & 6.947169 & 3 & 0.0736 \\
\hline D(LnMQ) & 8.590180 & 3 & 0.0353 \\
\hline D(LnEWG) & 6.509771 & 3 & 0.0893 \\
\hline All & 18.15795 & 9 & 0.0334 \\
\hline Dependent variable: D(LnMAN) & \\
\hline Excluded & Chi-sq & df & Prob. \\
\hline D(LnFI) & 2.390694 & 3 & 0.4954 \\
\hline D(LnMQ) & 84.06309 & 3 & 0.0000 \\
\hline D(LnEWG) & 14.25531 & 3 & 0.0026 \\
\hline \multicolumn{5}{|c|}{ All } & 158.4426 & 9 & 0.0000 \\
\hline Dependent variable: D(LnMQ) & \\
\hline Excluded & Chi-sq & df & Prob. \\
\hline D(LnFI) & 4.111670 & 3 & 0.2497 \\
\hline D(LnMAN) & 3.899073 & 3 & 0.2726 \\
\hline D(LnEWG) & 28.52271 & 3 & 0.0000 \\
\hline All & 43.69325 & 9 & 0.0000 \\
\hline Dependent variable: D(LnEWG) & \\
\hline Excluded & Chi-sq & df & Prob. \\
\hline D(LnFI) & 8.016794 & 3 & 0.0457 \\
\hline D(LnMAN) & 3.171841 & 3 & 0.3659 \\
\hline D(LnMQ) & 3.265955 & 3 & 0.3524 \\
\hline All & 14.77972 & 9 & 0.0972 \\
\hline
\end{tabular}

Table no. 9.

\section{Conclusion}

The study has employed two methodologies, one is statistical analysis and another econometric analysis in order to see whether industrial sector at the sub-sectoral level contribute towards foreign investment inflows in the country for the time period 1996-97:Q1 to 2009-10: Q2. The regression results reveal that all the sub-sectors of the industrial sector influence foreign investment inflows (i.e manufacturing sector, mining and quarrying sector and electricity water and gas supply). The econometric results reveal that all the sub-sectors of the industrial sector cause foreign investment inflows. However bidirectional causality is observed only in case of foreign investment inflows and electricity gas and water supply.

The benefits of foreign direct investment in India can be maximized by improving local conditions. Amongst the many ways by which foreign investment can help to enhance a country's manufacturing and export competitiveness, one way is to attract export oriented foreign investment and to ensure that such investment translates into development gains. What is needed is a country needs to find the most effective ways to make the choice of locations as well as the target segments, conducive to the kind of export activities the MNCs aim to foster. In the manufacturing sector in order to strength linkage between local and foreign companies openness to trade appears to be an important factor.

In order to promote linkages not only within sectors but also across sectors what is needed is development of human capital and proper promotion of local entrepreneurship. To support the 
process of off shoring higher value-added services to India there is need of sufficiently skilled labour as well as adequate infrastructure particularly telecommunications so that the dissemination of the benefits of IT-related services happens throughout the Indian economy. A growing number of Indian firms have gained technical expertise to run factories and firms across the globe, leveraging their domestic competence and in turn to acquire technology to enhance their domestic capabilities. It is quite true that infrastructure bottlenecks are disrupting industrial progress. Till 1991, the public sector provided much of the infrastructure, but is poor supply was often blamed because of lack of resources, enormous cost and time overruns in project completion and poor public management in general. The reforms have encouraged entry of private and foreign capital in these industries due to these problems of public ownership. In infrastructure services there is long gestation period and they are capital intensive with low rates of return spread over a long period. They are often networked industries, where efficacy of an individual plant or a firm depends on the performance of the entire network and financial returns depends on output pricing which are public policy decisions. In such industries foreign investment is fraught with risk, as evidence world over can testify. (Wells and Gleason 1995).

The foreign investor dislikes the procedural delays. The complex procedural compliance measures with time intense administration process, followed by bureaucratic attitude of the administrative staff and numerous authorities from whom clearances and approvals to be obtained leads to severe concern for investors because it affects both their costs and time management. According to most of the investors the projects handled at central level are much more organized and structured compared to projects handles at the state level. While foreign investment inflow in the manufacturing sector is upbeat and encouraging but there are some areas where foreign investors show their dissatisfaction. The mining sector is an alluring venture with the government leaving no stone unturned to make it investor friendly. The mining sector is encountering enormous growth with contribution to GDP in 2009-10 indicating an increase of $8.7 \%$ over the preceding period. So, mining is an exciting sector for potential investors to venture in India with the FDI investment policy in the mining sector liberalized over the years. The electricity, water and gas supply sector saw immense growth after independence due to both government and foreign investments. This is the sector which contributed most to the industrial sector in the planned development period.

Foreign direct investment was attracted in a variety of sectors after the liberalization process in 1990s. Various factors contributed to huge FDI inflow in India like the large computer hardware market in India, availability of skilled and trained labor force, increasing demand for exports in the country. A large number of companies are changing their manufacturing base to India as the country is rapidly rising as a worldwide manufacturing hub drawing more investors towards it. Other than Japan, India has the largest number of companies which is recognized for excellence in quality.

Overtime with advance stages of industrialization the significant and positive association between manufacturing and services sector gets stronger. The growth of these two sectors are interrelated in many aspects as for example the development of the manufactured inputs affects the growth of the services sector, similarly with the economic growth taking place the manufacturing sector's demand for certain services like trade, transport, hotel, banking and social services such as education, hospitals and other infrastructure related services increases. Investment in the basic infrastructure i.e. electricity gas and water supply will be beneficial for economic growth and efforts to draw private investment into infrastructure through the PPP route have met with considerable success, both at the Central level and state level. 


\section{References}

1. Alfaro L., 2003. Foreign direct investment and growth: Does the sector matter? Boston, MA: Harvard Business School, Mimeo.

2. Aykut D., Sayek S., 2007. The role of the sectoral composition of foreign direct investment on growth. In L. Piscitello, \& G. Santangelo (Eds.), Do multinationals feed local development and growth? London: Elsevier, pp.35-62.

3. Dickey D.A., Fuller W.A., 1979. Distribution of the estimations for autoregressive time series with a unit root, Journal of American Statistical Association, 74(366), pp.427-431.

4. Engle R.F., Granger C.W.J., 1987. Cointegration and Error-Correction: Representation, Estimation, and Testing, Econometrica, 55(2), pp.251-276.

5. Findlay R., 1978. Relative Backwardness, Direct Foreign Investment and Transfer of Technology: A Simple Dynamic Model, Quarterly Journal of Economics, 92(1), pp.1-16.

6. Johansen S., 1988. Statistical Analysis of Co-integrating Vectors, Journal of Economic Dynamics and Control, 12(6), pp.231-254.

7. Johansen S., Juselius, K., 1990. Maximum Likelihood Estimation and Inference on Cointegration with Application to the Demand for Money, Oxford Bulletin of Economics and Statistics, 52(2), pp.169-210.

8. Kathuria V., 2002. Liberalization, FDI and Productivity Spillovers- An Analysis of Indian Manufacturing Firms, Oxford Economic Papers, 54, pp. 688-718.

9. Kwiatkowski D., Phillips P.C.B., Schmidt P., Shin Y., 1992. Testing the Null Hypothesis of Stationarity against the Alternative of a Unit Root, Journal of Econometrics, 54 (1-3), pp.159-178.

10. MacKinnon J.G., 1991. Critical Values for Co-integration Tests. In Engle, R.F. and Granger, C.W.J. (Edrs.), Long Run Economic Relationships: Readings in Co-integration, Oxford: Oxford University Press, pp.267-276.

11. MacKinnon J.G., Haug A. A., Michelis L., 1999. Numerical Distribution Functions of Likelihood Ratio Tests for Cointegration, Journal of Applied Econometrics, 14(5), pp.563577.

12. Phillips P.C.B., Perron P., 1988. Testing for a Unit Root in Time Series Regression, Biometrika, 75(2), pp.335-346.

13. Rodriguez-Clare A., 1996. Multinationals, Linkages and Economic Development. American Economic Review, 86(4), pp.852-873.

14. UNCTAD, 2001. World Investment Report 2001. United Nations, New York and Geneva.

15. Wang J. Y., Blomström M., 1992. Foreign Investment and Technology Transfer; A Simple Model, European Economic Review, 36(1), pp.137-155.

16. Wells L.T., Gleason E.S., 1995. Is Foreign Infrastructure Investment still risky? Harvard Business Review, pp.44-53. 